\title{
Development of small business in Ukraine and Poland: point of contact and problematic aspects
}

\author{
Olena Sorokivska \\ Ivan Pu'uj Ternopil State Technical University \\ 46001, Ruska str. 56, Ternopil, Ukraine \\ Tel/Fax: +380352252976 \\ E-mail:inter@tu.edu.te.ua \\ Olga Boryk \\ Ternopil Institute of Social and Information Technology \\ Ternopil, st. Tantsorova 51. \\ TellFax: +380 (352) 52-83-10, 25-24-43 \\ E-mail: boryk_olya@ukr.net
}

Abstract. The aim of the presented paper is to determine the place and role of small busi-

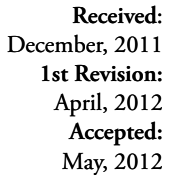
The main objectives of the study are: defining the place and role of small business May, 2012 formation in the economy of Poland, doing characteristics of the existing enterprises by number of employees and analyze the share of small enterprises in the sector, determining the main reasons for the growth of entrepreneurship in small business sphere; studying the formation of partnerships relationships between the subjects of small business in Ukraine and Poland in the priority sectors; making the definition of institutional support and features state aid in the development of small businesses.

The results of the research is to determine the small businesses impact on the sectoral structure of economy forming in Ukraine and Poland, in grounding features of small businesses in two countries, analytical comparisons of the Polish-Ukrainian economic cooperation.

Keywords: small business, government support, institutional structures, investment projects, economic growth.

JEL Classification: F23, P2.

\section{INTRODUCTION}

The small business sector in European countries is important for the development and stabilization of the socio-economic processes. Due to the functioning of small enterprises it is provided employment, 
emerging of new markets for products and services, increasing the quality of life of society. This small business provides $60-70 \%$ of Poland, Hungary, Belgium, Romania and other European countries GDP [2]. However, this area is very vulnerable to various adverse effects, that's why the success in many countries in the promotion and development of small business are taking place through the provision and strategically directed policy.

\section{THE RECENT RESEARCH AND PUBLICATIONS ANALYSIS}

The support and development of small businesses are quite relevant, because this problem is highlighted in the writings of N. M. Zayarna, N. A. Gnat, T. N. Pihnyak, S. K. Reverchuk, A. D. Vovchak, L. L. Tsymbal. However, it is poorly understood the issue of Polish experience using in the national economic system.

\section{THE PROBLEM DEVELOPMENT}

The main objective of the research is to combine the positive aspects of Polish and Ukrainian experience of small businesses supporting and explore the features of its development in the two Slavic countries.

\section{THE MAIN MATERIAL}

Ukraine on the business environment is one of the most risky countries in Europe. Among a number of other indicators that is shown about this is a crucial index of ease of doing business that was founded by the World Bank to compare the ease of doing business between countries. Higher score in the index indicates about more efficient business regulation and stronger degree of protection of various forms of ownership in a particular country. In 2011, Ukraine ranked 145th place according to the criteria of last report, having lost two positions compared to 2010 [5].

In today's difficult political and economic conditions for small business in Ukraine it is worse to borrow some positive moments of small businesses supporting in neighboring Poland because historical and political background of the economic environment of the two countries in many respects is similar

This progressive transformation in the business field allowed Poland to join the EU. Economic indicators of the Polish economy development show the effectiveness of reforms. So, today in Poland, a small business become the main driving force of the market economy formation and integration of this country in the world economy.

On enhancing the role of SMEs indicates the following indicators. Thus, at the end of 2011, the share of SMEs in the total employed population was about $62 \%$, the share of SMEs in GDP - $47-48 \%$ and the share of SMEs in the total number of enterprises - 99\% [6].

According to the classification of the Polish Central Statistical Bureau (CSB) the companies with a staff of 50 refers to small businesses enterprises, to the medium - from 51 to 200 people. In 2011, the share of SMEs in creating GDP in Poland amounted to 48\%, in $2010-45 \%$, and in $2009-40 \%$, taking into account the shadow economy $-44 \%$. According to CSB, every year it is constantly decreasing the share of shadow economy due to the continued growth performance of SMEs and their share in GDP. Given the scale of percentage of GDP creation by $100 \%$, the largest contribution to the devtlopment of Poland economy is made by trade and repair businesses $(94 \%)$, the second place is followed by the companies that operate 
in real estate and business services (92\%), the third - construction companies and companies engaged in restaurants and hotels (80\%), then - the production and transport accounted for 45\% [1].

In late 2011 there were 1,583,606 enterprises operating in the manufacturing sector (excluding financial intermediation units), and their number raised at 239,983 compared with the end of 2010.

The increasing of operating enterprises was higher than the net increasing of objects registered in the civil registration system, approximately 85,000 units.

From the total number of operating enterprises, 1,577,806 were private firms. In 2011 compared with 2010, the number of public sector enterprises decreased by 508 units. This was primarily a consequence of the National Investment Fund (NFI) program. In 2011, the ratio of operating companies with their registered number was $64.8 \%$, almost $5 \%$ more than there were for the previous year.

In 2011 there were 1,567,413 small businesses, representing approximately $99 \%$ of all companies operating in Poland. So, there were 12,774 (about $0.8 \%$ ) medium and 3419 large enterprises (table 1).

Table 1

Description of existing enterprises by number of employees [1]

\begin{tabular}{|l|c|c|}
\hline \multicolumn{1}{|c|}{ Type of enterprises } & The number & Share, $\%$ \\
\hline Small (0-50 employees) & 1567413 & 98,98 \\
\hline Medium (51-250 employees) & 12774 & 0,8 \\
\hline All small-medium enterprises & 1580187 & 99,78 \\
\hline Large (more than 250 employees) & 3419 & 0,22 \\
\hline All number of enterprises & 1583606 & 100 \\
\hline
\end{tabular}

There are $41.1 \%$ of the total number of existing SMEs in the sector of trade and repair. Existing production facilities constitute $13.4 \%$, while $11.7 \%$ are the building companies. Almost the same value (11.5\%) in the sector of SMEs are in relation to the companies operating in real estate and business services sector. The total number of small and medium enterprises that are engaged in transport and communications sector, is $9.8 \%$. The share of $4.2 \%$ belonge to the objects that work in health care (medical, dental and veterinary clinics).

Approximately $4 \%$ of the total number of SMEs so-called "other services" (eg, dry cleaners, cosmetics, funeral services, as well as in the fields of culture and sports). The relatively low number (3.2\%) of SMEs are working in the sector of the restaurant and hotel business.

With the exception of mining, electricity, gas and water sector institutions, also health sector, where private enterprises are still playing important role, a small business in construction has the fastest growth. It is $38 \%$. Other sectors that grew the most rapidly thanks to small business development are hotels and restaurants - $28.5 \%$, other services $-24.4 \%$, real estate and business services $-19.5 \%$. The growth rate of small businesses operating in transportation, communications, is $16 \%$, trade and repairs $-14.3 \%$, in manufacturing $-9.5 \%$.

Threats for business sector of small and medium enterprises that have emerged after Poland joining the EU, that is connected with the labor market, are concentrated in two main areas: possible increasing of the labor and social costs, difficulties conserning of finding qualified staff, which may be caused by the skilled staff movement.

According to the survey conducted by the Polish Foundation of Small and Medium Enterprises Support and Development, SMEs often need government support (table 2). 
Results of statistical analysis of the Polish SMEs needs in public assistance,\% [2]

\begin{tabular}{|l|l|}
\hline \multicolumn{1}{|c|}{ Classification feature of the company } & The share of respondents that gave a positive response \\
\hline Profile of the company & \\
\hline - production & 93 \\
\hline - service & 52 \\
\hline - building & 47 \\
\hline - trade & 34 \\
\hline Size: & \\
\hline Micro (less 5 employees) & 25 \\
\hline Small (6-50 employees) & 69 \\
\hline Middle (51-250 employees) & 82 \\
\hline Big (more then 250 employees) & 37 \\
\hline
\end{tabular}

Similarly, respondents, which included representatives of SMEs, indicated that the aid is more needed for medium-sized enterprises and smaller - big trading companies.

Such companies find out that the most serious threats are associated with the performance of the business, reducing the share of products on the market, loss of income or lack of profitable activities. Almost half of all market participants saw a real threat to reduce sales by competition increasing. Every third entrepreneur is afraid that he will be forced to discontinue business activities by its unprofitability.

This government support has helped small and medium enterprises in Poland to achieve positive developments. During 1995-2011 years the Polish government has launched and implemented a series of progressive reforms that were intended to create a favorable investment climate for small business development and provide infrastructure for its functioning (table 3).

Table 3

The most important institutional structures that are established in Poland to support and develop small businesses

\begin{tabular}{|l|c|c|}
\hline \multicolumn{1}{|c|}{ Year } & The title of institution & Main functions \\
\hline 1995 & $\begin{array}{c}\text { Polish Foundation for Support and } \\
\text { Development of Small and Medium } \\
\text { Enterprises }\end{array}$ & $\begin{array}{c}\text { Providing effective interaction 240 agencies and institutions to } \\
\text { support small business; } \\
\text { - maintaining cooperation with the Government and Parliament, } \\
\text { providing accurate and analytical information on small business. }\end{array}$ \\
\hline 1997 & $\begin{array}{c}\text { National Fund of loan guarantees } \\
\text { - a network of regional funds to support agricultural development } \\
\text { and depressed regions. }\end{array}$ \\
\hline 1997 & Agency of Technology & $\begin{array}{c}\text { Promoting the development of innovative technologies and their } \\
\text { application in small business }\end{array}$ \\
\hline
\end{tabular}

The "Capital for Entrepreneurs" (2002-2006) is the program that aimes mainly at improving the efficiency and attracting external funding for the business needs of small business sector.

As a result of ratifying the European Charter of Small Business Poland's accession to the European Union, small business found itself in a favorable environment for market expansion, access to advanced technologies and establishment of international cooperation. 
In 2003 the government introduced preferential tax rates for newly established enterprises and enterprises that create jobs; bankruptcy procedures, strengthening of credit guarantees for small businesses and assets of small business lending. The "Capital for Entrepreneurs" (2002-2006) is aimed mainly at improving the efficiency and attracting external funding for the business needs of small business sector.

As a result of ratifying the European Charter of Small Business, Poland's accession to the European Union, small business found itself in a favorable environment for market expansion, access to advanced technologies and establishment of international cooperation.

Draft World Bank "Doing Business - 2011" highly appreciated the positive experience of Poland in the formation of the small business sector and awarded the country for 70 place in the ranking of 183 countries participating.

Today, Poland is the largest trade partner of Ukraine among Central and Eastern Europe and is for 11 months in 2011 fifth among countries (pic. 1).

Following 11 months of 2011 the volume of foreign trade between Ukraine and Poland amounted to 5441.0 million US dollars. The level of Ukrainian exports to Poland was 2543.6 million US dollars, compared to the rates in 2010 it was increased by $58.9 \%$. Level of Polish imports to Ukraine - 2897.4 million US dollars and compared with the figures of 2010 it was increased by $14.9 \%$ [3].

The negative balance in foreign trade with Poland - for 11 months in 2011 was 353.8 million US dollars.

The volume of foreign trade services of Ukraine and Poland as a result of 9 months in 2011 (the latest data as of 19.01.12.) increased by $21.7 \%$ from same period in 2010 and amounted to 187.9 million. USA. The level of Ukrainian exports of services to Poland for 9 months in 2011 amounted to 93.2 million US dollars, and the level of Polish imports of services in Ukraine - 94.7 million US dollars.

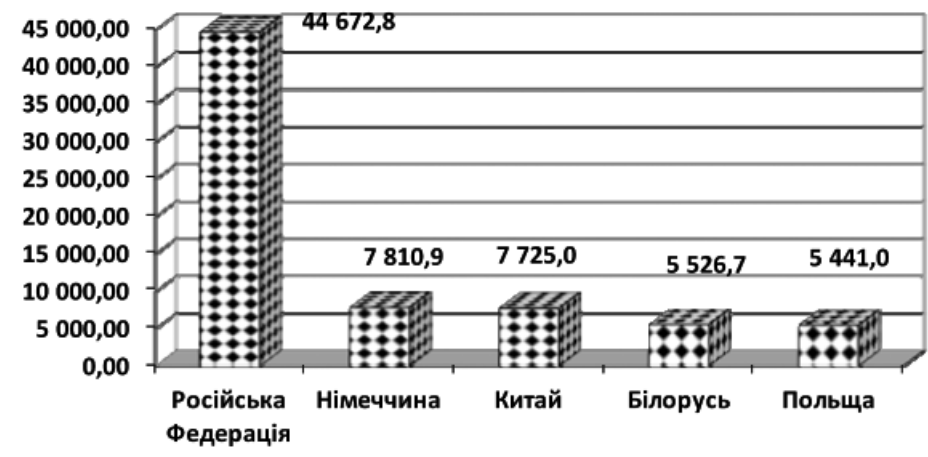

Picture 1. The volume of foreign trade with major partners of Ukraine, mln US dollars [3]

According to preliminary data from the Ministry of Economy of Poland, for 11 months in 2011 the volume of foreign trade of Ukraine with Poland amounted to 4897.6 million (640.3 million US dollars). The volume of Ukrainian exports to Poland was 816.0 million euro (2 462.2 million US dollars) and increased by $47.1 \%$ compared to same period of last year. The volume of Polish imports to Ukraine amounted to 3081.6 million (4 178.1 million US dollars) and increased by $13.4 \%$ against same period of last year. Negative for Ukrainian trade balance was 1265.6 million (1 715.9 million US dollars).

As of October 1, 2011 the volume of Polish investment in Ukraine totaled 890.2 million US dollars, representing $1.9 \%$ of total foreign investment in Ukraine (pic. 2). From the beginning, there has been the 
outflow of Polish investments. As of January 1, 11 there were 933.4 million US dollars of them, as of July 1, 11 it was 894,4 million US dollars, as of January10, 11 - 890.2 million US dollars.

According to the State Statistics Committee of Ukraine, the volume of Ukrainian investments in the Polish economy as of January 10, 2011 totaled 49.5 million US dollars, representing $0.7 \%$ of the total volume of Ukrainian investments abroad. According to available information, the amount of actual Ukrainian investments in Poland, which for various reasons do not count the Ukrainian statistics, is more than \$ 1 billion US dollars. In Poland there are at least a dozen companies with the Ukrainian capital.

The most significant Ukrainian investment projects in Poland are: Steel Mill "Huta Czestochowa" (investor - "ISD”), Shipyard “Stochne Gdańske” (investor - “ISD”), “Guta Pokuy” (investor - "Private”), Plant of lighting "Helios" (investor - "Spark"), Warsaw car plant (investor - "Auto-ZAZ”), a fruit processing plant “T.B.Fruit Dwikozy” (investor - company “T.B.Fruit” (owner of the trademark "Apple gift”) .

935,8

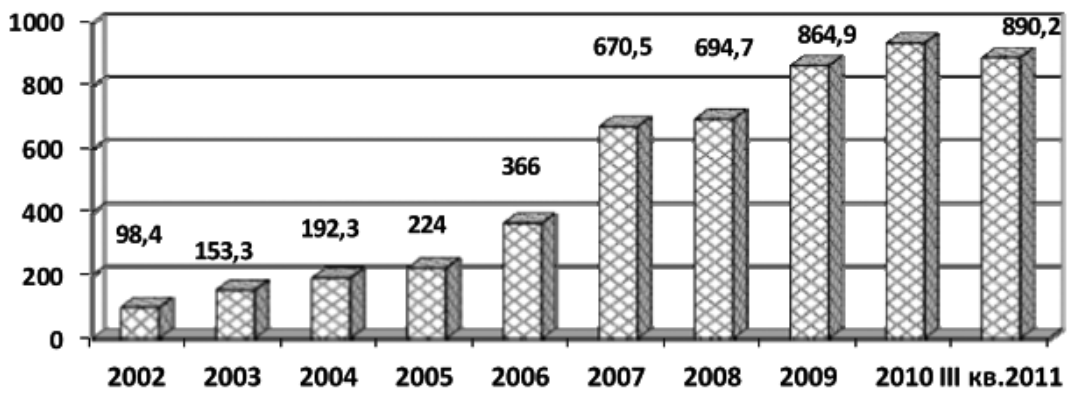

Picture 2. Dynamics of Polish investments in Ukraine (million dollars. USA) [4]

The most significant Polish investments in small and medium enterprises in Ukraine are: building ceramics factory "Cersanit", parquet factory "Barlinek", Furniture Factory "New Style", packing factory "Ken-Pack", factory auto parts "Inter-Hroklin", metal factory processing "Polimex-Mostostal".

Today, Polish investors gradually start shifting the emphasis from conventional production, concentrated in small business (building and decoration materials, wood, paint industry, etc.) in the direction of modern industries, providing high level information technology development. Already there is a serious growing interest of Polish investors in the Ukrainian media market (after opening in 2007, one of the largest Polish publishing company Agora of the Ukrainian branch of Agora Ukraine Ltd., this market is actively interested in other powerful media group in Poland - TVN). In addition, the Poles are increasingly attracted to the cooperation of Ukrainian programmers. In particular, the Cracow Technology Park, which are well-known international companies such as Motorola, Delphi, Onet, Interia, ComArch etc., working with Ukrainian experts in the field of information technology and Wroclaw authorities even developed a special motivation program for talented Ukrainian. In the future, such a partnership can develop in the creation of technology parks, with the participation of Polish capital in Ukraine, including Lviv, Volyn and Ivano-Frankivsk. This allows to expect a high level of domestic personnel relevant universities and higher percentage learners of Polish among Ukrainian specialists and university graduates. Very important in services innovation, particularly in tourism and recreation industry, which in terms of the Ukrainian-Polish investment cooperation is one of the highest priority and potentially competitive in the international market. Moreover, some recrea- 
tional resources, both Poland and Ukraine, have a unique character that makes them the object of attention from wealthy Western consumers and investors.

\section{CONCLUSIONS AND PROSPECTS FOR FURTHER RESEARCH IN THIS DIRECTION}

Therefore, cooperation in the sector of small business in Ukraine and Poland will allow business entities of both countries to exercise effective development by acquiring new knowledge, dissemination of scientific advances and technological "know-how", training of human resources. The analysis of statistical data on the volume of trade transactions and investments in both countries shows the great potential of economic cooperation. However, the success of such cooperation is largely dependent on state support of small business in each country. Prospects for further research in this direction is the study of major trends and dialectical development of the Ukrainian-Polish economic relations and identifying of government support needs in terms of sectoral and regional small business development in Ukraine and Poland.

\section{LITERATURE}

Goncharov E. V., Analysis of the Polish social and economic practices of public administration development of the region, electronic resource. Mode of access: http://www.nbuv.gov.ua - Vernadsky National Library.

Zayarna N. M., Gnat N. A. International experience of small business supporting and current Ukrainian realities, Scientific Bulletin of the National Forestry University of Ukraine 2011. - No. 3. - S.198-202.

The volume of foreign trade with major partners of Ukraine in 2011, electronic resource. Mode of access: http://www. ukrstat.gov.ua - State Statistics Committee of Ukraine.

The volume of investments to Ukraine in 2011, electronic resource. Mode of access: http://www.ukrstat.gov.ua - State Statistics Committee of Ukraine.

Status and prospects of Ukrainian-Polish relations: trade and economic cooperation, electronic resource. Mode of access: http://www.mfa.gov.ua - Embassy of Ukraine in Poland.

Eastern Partnership: trends and perspectives, electronic resource. Mode of access: http://www.kijov.polemb.net - Embassy of Poland in Ukraine. 